\title{
Politics of Hunger and Development: A Sociological Review of India's Developmental Discourse
}

\author{
Ashok Kumar M. \\ School of Humanities and Social Sciences, Indian Institute of Technology Mandi, Mandi, India \\ Email: ashok@iitmandi.ac.in
}

Received August 5 ${ }^{\text {th }}, 2012$; revised September $4^{\text {th }}, 2012$; accepted September $13^{\text {th }}, 2012$

\begin{abstract}
This paper attempts to address the problem of hunger from the viewpoint of its social face against the backdrop of fast growing economy of India. Current sad state of affairs in the domain of poverty and hunger are nothing but the cumulative result of what happens in the Indian development planning since Independence, or at least in the name of development planning. This paper sociologically examines three most critical events in the history of Indian development planning, which are introduced to mitigate hunger and poverty, in both urban and rural India. The central focus of this paper is to highlight politics of those development initiatives and liquidation of public planning at the level of implementation, which eventually increased the gap between rich and poor, and left the Indian poor to their own fate. This paper also examines the most significant aspect of delinking power relations from the development discourse of India by providing more room for populist ideas with an aim to gain political mileage by the ruling elite. The present state of affairs with respect to poverty and hunger coupled with low standards of health, literacy and social awareness in India call for serious introspection. This paper, therefore, critically looks at Indian development discourse from the perspective of power relations, both established and emerging, which could alter our views on India and its growth story.
\end{abstract}

Keywords: Development; Political Economy; Hunger

\section{Introduction}

India is one of the fastest growing economies in the world today but it still struggles to eradicate the most alarming problem of hunger and acute poverty, which is widely visible in every corner of the country. India ranked 67 in the Global Hunger Index (GHI) 2011 conducted by the International Food Policy Research Institute (IFPRI) among 81countries across the world. India's neighboring countries seem to have done fairly well, while China ranked 4, Pakistan ranked 59 and Sri Lanka ranked 36 in the GHI. This Global Hunger Index is calculated taking three interconnected dimensions of hunger-inadequate consumptions, child underweight, and child mortality-into consideration. The same report placed India in the "alarming" category. It clearly points out that India is home to $42 \%$ of the underweight children under the age of five. These aspects of India evidently demonstrate the sorry state of affairs that needs a serious thought and it also calls for sociological explanation. In its attempt to become more responsible, Supreme Court of India has directed the government on 12th August 2010 to distribute food drains remained at the FCI (Food Corporation of India) warehouses as backlash to the incident of 50,000 tonnes of wheat being destroyed and damaged due to the poor and insufficient storage facilities.

When the union minister of agriculture Mr. Sharad Pawar responded to supreme court's ruling that it was not possible to implement the Supreme Court's suggestion to distribute the food grains for free, then the Supreme Court had reiterated saying that distribution of food for free was not a suggestion but an order. It is quite stunning to come across such observations when the Indian economy is thriving in the global market.
India’s impressive economic performance in the global market and its utterly poor performance in eradicating hunger raise many questions about social inequality, political will, good governance, development initiatives, and above all the much talked about concept of inclusive growth. This paper goes into socio-historical aspects of Indian realities with reference to poverty and hunger to explain the current state of affairs.

\section{Concept of Development and Hunger}

The problem of hunger in India is, undoubtedly, viewed by many social scientists, as a multi-headed monster whose roots are strongly embedded in the Indian social structure, and is one among the most serious social problems that contemporary India is confronting today. This problem of hunger draws its origins from low levels of education, high levels of superstitions, lack of awareness, the caste system, unequal distribution of wealth, and ever increasing population. That means any holistic study of hunger must not be independent of Indian social structure in terms of both theory and application. The problem of hunger is one among the most striking features of underdevelopment in Indian society. The notion of underdevelopment and its special relationship with the problem of hunger is inseparable. The discourse of development has been put forth as the most desirable way out to mitigate the problem of hunger and poverty. Defining the concept of development has been and continues to be a great challenge to many theorists as it involves multiple dimensions such as social, economic and political, which are of complex and multilayered in nature. But in a day to day parlance, development denotes either a state of well-being or a process associated with concepts such as mate- 
rial well-being, economic growth, social justice, personal blossoming and, of course, ecological balance.

The United Nations definition of development is as follows:

The ultimate purpose of development, according to a UN document 1975, is to bring about a more equitable distribution of income and wealth for promoting social justice; alleviating poverty; maximizing productive employment; and expanding and improving facilities for education, health, nutrition, housing and social welfare for the deprived and dis-advantaged individuals, groups and communities. These objectives, the documents said, are both the determining factors and the end result of development and hence be viewed as integrated parts of a dynamic development (Srivastava, 1998).

Various models, approaches, theories and strategies that have been extensively used in development literature have comprehensively explained the process of development. It is important to note that there is no single development model, which is universally accepted but at the same time the concept of economic growth seems to be at the heart of all development models, it is precisely true in case of developmental models that have had western origins. It is argued that the entire conceptual pragram of modernization and development doctrines since 1945 have embodied the cultural assumptions, political premises and economic values of the western society (Luke, 1990). As a result, we face a strange situation wherein one finds discourses of development and modernization strongly rooted in the cultural, technological, historical and political premises of North America and Western European society rather than in the actual needs and real experiences of the Third world countries on whose behalf the demand for development is being strongly advocated. The dominant Western development paradigm being “economic growth" centered was subjected to severe criticism when the question of applicability in Indian social context is brought-forth. Some even argue that perhaps it is inevitable to India's development discourse to avoid western dominant model in its journey towards developing an indigenous model of development.

On similar lines, many scholars argued that the critiques of modern development theories are not only restricted to alternatives, but also based on a search for more satisfactory and indigenous forms of development, which are perhaps much different from the western development theory. We do come across many development models that are of Indian origin like Gandhian model, Nehruvian model and Kerala model and so forth. This means that here one is not looking for universally accepted development model but trying to make sense in a

\footnotetext{
${ }^{1}$ It is quite possible to see many non-poor having the experience of hunger due to good reasons like disparity in intra-familial distribution of power, land and other property difference and also due to family problems and so forth. But the kind of hunger that non-poor undergo is not the concern of this paper. Even chronic-hunger as a consequence of natural calamities also does not come under the purview of this paper. In fact, hunger could really be an outcome of both illegal transfers (e.g. looting) and choice failure (e.g. owing to inflexible food habits) by an individual (Mukherjee, 2002). In a way this study expresses its sensitivity towards different forms of hunger though they were not dealt with in this essay.

${ }^{2}$ Acute hunger, which is a result of famine, is more sensational, emotive and apparent from the outset. On the other hand, chronic hunger is insidious sabotage wrought on millions of children, women and men in several places around the globe. It is silent and only the sufferers hear the growls in her or his stomach. In case of India, particularly, many may not be "dying of hunger” but they spend their whole live at the edge of hunger.
}

contextually valid ways. However, in many ways, there seems to be a commonality among the definitions of development that they always get defined as opposite of underdevelopment. It contains a promise of moving away from underdevelopment and rising out of poverty, which is sought and perhaps attained by means of planning for development. The notion of "development" is believed to be potential enough to provide the way out for poverty and hunger problems and in other words it carries, in some sense, a "believability structure" which has always been taken for granted.

Since it carries a sense of "believability structure", there has been a high level of competition among people belonging to different fields or domains to capture this emerging "social domain" called development. Among social scientists, in fact, economists are relatively successful enough to capture this area a little earlier than the others. As a result, economic perspective has been dominant in the development discourse all over the world and India is no different. In this paper my focus is to understand the problem of hunger in India from a sociological perspective by giving a special emphasis on non-economic dimensions or "social face of hunger". This social face of hunger has the potential to run through the Indian history in the discourse of development. The same framework would allow us to pose different questions, provide perspectives for new interpretations in my attempts to understand questions of hunger and poverty in India.

Before making any arguments on hunger in India, I would like to clarify the sense in which the term hunger is being used in this paper. Hunger could be a potential outcome of many situations ${ }^{1}$ but the one I want to address in this paper is a day-to-day experience of "Indian poor". This form of hunger is intrinsically associated with poverty stricken conditions of Indian society. According to Amartya Sen, hunger is classified into two major categories, one is of "acute hunger" and the second one is "chronic hunger" 2 . The chronic hunger among Indian poor occupies the center stage in my analysis. Paradoxically, the stark social reality lies in the fact that people or social groups who suffer from chronic hunger have direct and active involvement in the process of food production in India (Sen 1991). Jean Dreze has been emphasizing on a fact that India does not have food scarcity but it seriously suffers from unequal distribution of food amongst people that in turn leading to hunger (Dreze, 2003, 2004).

Economic status as bottom line for identifying poor has been an established practice in the development discourse in India. Besides economic factor, it would give us a better understanding about poverty and hunger situation in India by considering dazzling differences between urban and rural population, people live in wet land and dry land, gender differences, and most importantly differences between the lower castes and upper castes. This argument is to highlight that Indian population of a particular region is not a homogenous group to apply economic perspective to calculate who is poor and who is not, purely on the basis of their economic status. The social/caste group they are born and brought up with could largely influence and decides their chances of social opportunities in life.

Having a vast population who are suffering from hunger in India itself speaks volumes about the intensity of hunger problem and the way it has been addressed at the level of planning. The presence of poor people is not only confined to dry-lands rather their presence is equally represented in wet-land areas too. In general, human beings like all living beings do not opt 
to be hungry unless they are forced to be so. Poverty and hunger in India must not be examined as independent entities rather an essential outcome of Indian politics throughout the past five decades since Independence. With urgency one should pose this question i.e. why the question of hunger was/is not in the forefront of Indian political discussions despite its significance and disturbing figures it presents. The very premise to bring about positive changes in any society is through none other than "political will” with and without the support of state ${ }^{3}$. Unfortunately such "political will" in Indian politics is either absent or hypocritical; as a result social problems like hunger are hardly discussed in the public debates or in the gatherings of public representatives. There are many official schemes in India even today that try to address hunger problem directly or indirectly. It is interesting to know that some government-initiated schemes are highlighted and got undeserved attention than the actual outcome yielded by those schemes.

\section{Politics of Hunger and Historical Betrayal}

\section{Land Reforms}

Right after the Independence, one of the major concerns of rural India was to provide minimal agriculture land, as part of distributive justice, for the landless agriculture laborers. After conducting agricultural census, many Indian States legislated the fixed ceilings during the second Five Year Plan (19561960). These Land Reforms of 1960s, with its regulations regarding tenancy and ceiling on agricultural land holdings are supposed to break up large estates in order to reduce social disparity between the landlords and the poor, and also to provide solution to the problem of hunger in India. The former Prime Minister (PM) of India Mrs. Indira Gandhi herself declared at the Chief Ministers conference during 26-27 September 1970 that "land reforms is the most crucial test which our political system must pass in order to survive” (Lal, 1982). Unfortunately, the Indian political system has been surviving without taking any measures or action to implement land reforms. It was estimated that the surplus land would be around 5.3 million acres, out of which not even $2 \%$ of land got distributed over a period of thirty-five years of agriculture land ceiling enforcement (Lal, 1982). Even today, there are people who illegally own hundreds of acres of agriculture land in rural India: it has become an elephant in the room.

The most striking and prominent reason behind failure of land reforms implementation was the emergence of landlord castes into a powerful political lobby or force in the post-independent India with strong intentions of protecting their vested interests. It is the same landlord castes or the rural elite, if I may call them, is the social base for all the political parties in India irrespective of their ideological differences. Given significant importance to the landlords in the political circles of India, the Landlord castes ensure that manipulating the process of implementation defeats those policies, which may cause damage to their social domination, political economy and landholdings. Due to loopholes and lack of sincerity, Indian landlords could manage to retain their landholding through binami names. It was believed that government officials who

\footnotetext{
${ }^{3}$ The usage of the term "state" here implies that it is an autonomous entity that can be operated irrespective of political parties holding the power. Importantly, there is a growing tendency of hatred and disinterest towards active politics among Indian youth in recent days; popular perception says that politics is the business of corrupt and also rich people.
}

involved in the enforcement of land ceiling act were quite often in favour of landlords. The nexus between Landlords, Indian bureaucracy, and the political class stood united against implementation of land reforms, as a result the size of large landholdings reduced only on the government records but not in reality. Many studies (Lal, 1982; Rao, 1974; Joshi, 1996) have suggested that the fruits of land reforms cannot reach the rural poor unless their direct involvement in the program implementtation is ensured.

The reason behind giving an extra emphasis to land reforms had to do with the historical context in which it was introduced. It was introduced when the "agrarian unrest"was widespread in rural India. It was precisely due to the oppressive nature of caste system, colonial administration that hardly had any concern for the natives, Jajmani system which favored people from the upper castes in Indian sub-continent. Altogether, after Independence India had to face acute forms of poverty, enormous social disparity between the majority of its population who are poor and belonging to lower castes, on the other hand we had very rich and landlords who usually belong to one of the upper castes. This is what precisely led to agrarian unrest as an overwhelming proportion of India's agriculture land was in the hands of a few individuals against the rest who were landless. And not to forget, agriculture was one among the major sources of living for majority of Indians; that resulted in exploitation of laborers as the labour was cheaply available in the market. The "agriculture land" is considered an important source of income, besides being a symbol of higher social status. Agriculture land in Indian context has the potential to scale up one's social status by providing multiple options for living and income generating techniques. In this historical context, land ceiling enforcement act was an important "national promise" to its citizens in the post-independent India expecting that it would unleash social disparities between rich and poor. India's failure to implement the land reforms resulted in reproducing the same "Jajmani relations" with a different mode and style of operation under democratic political system.

\section{Green Revolution}

In another important attempt to address the problem of hunger and poverty in Indian society in the early 1960s the phenomenon of "green revolution" was brought forth in the national debate. The idea of green revolution and its importance was based on the FAD (Food Availability Decline) argument. The FAD argument was that majority of Indian population was going hungry because there was not enough food produced and hence less food available in the market. As a result, it was argued that there was a crying need for implementing HighYielding Variety (HYV) of seeds along with introduction of fertilizers and improvement in the irrigation system to produce more agriculture output in order to meet national needs. The Green revolution made many promises to the nation notably introduction of double cropping pattern, High-Yielding Variety seeds, and scale neutrality into the Indian agriculture system, all that to address the problem of Hunger in India. This green revolution technology was tested and tried in many parts of India but was partially successful in the states of Punjab and Haryana for a variety of socio-economic reasons like large average rate of land holdings, better irrigation facilities along with better economic conditions of the farmers in these two states. But the experience of green revolution technology left 


\section{A. KUMAR M.}

bad memories on the life of poor people as their problem of hunger and poverty remained largely unaddressed.

In order to understand the social and structural reasons for the failure of Green revolution technology in India, I think, it is necessary to go into the details of the structure of land ownership in India. It will be even clearer to understand the dynamic relationship between land ownership and poverty in India from the point of Amartya Sen's entitlement approach. For Sen (1981), the structure of land ownership and ownership relations are one form of entitlement relations. Therefore, it is necessary to understand the entitlement systems within which the problem of starvation needs to be analyzed. He argues that hunger is the result of non-.availability of food and lack of Individual ability to access food through endowment or exchange entitlement. Sen was critiqued by scholars on the grounds of his negligence towards taking cultural elements into his entitlement approach. Amitava Mukherjee argues that some serious structural and cultural issues related to food insecurity have been over looked in Sen's thesis. Satisfaction of both foods availability and individual's ability to access may not always guarantee food security. In Indian cultural context there are three more conditions in addition to Sen's argument, for food security. They are: existence of institutional sanctions, choice of food and the existence of secondary food system (Mukherjee, 2002).

Mukherjee further argues that Sen's E \& D thesis laid over emphasis on possession based ability wherein general ability is shaped and sharpened by available institutional sanctions and system of markets and prices. Also it would be important to know elements in individual's endowment entitlements. They have to be either objective goods like land, wealth, etc. or subjective goods like skill, knowledge, traits, aptitude, and capacity to work hard and so on. Both the objective and subjective goods in endowment entitlement of a person are interconnected closely with causal relation. Therefore individual possessiveness and capability cannot be determined effectively by any other factors other than objective goods they had. So there is no point of looking at individual's capacity by ignoring the source of its very being (Mukherjee, 2002).

The FAD argument conveniently neglects the fact that hunger, starvation and poverty depends not merely on food availability but also on its distribution. The advocators of FAD argument believed that increase in food production would be possible through Green revolution that will solve the hunger problem in India. The green revolution proved a turning point towards modernizing Indian agriculture sector. And due to the immediate effect of the introduction of new technology, HYV, unlike past it made the farmers increasingly dependent on the market for new seeds, chemical fertilizers and farm machines etc. Consequently, agriculture has become increasingly capital intensive. Quite a good number of farmers in rural area couldn't cope up with green revolution strategy of development, which proved to be a very costly affair given their poor economic standard (Das, 1983). Therefore the obvious inference that one can draw from this situation is that the gains or fruits of green revolution technology were only available at the doorsteps of those who were already rich enough ${ }^{4}$. Critics argued that the

\footnotetext{
${ }^{4}$ In India, Punjab and Haryana states have relatively better good irrigation facilities in agriculture sector compared to other. In addition to that, the average rate of land holdings is more than 15 acres in both these states against national average. That might be seen as one of the significant factors behind the relative success of green revolution technology in these two states.
}

green revolution has been responsible for accelerating the pace of mechanization and tractorization that caused displacement of the labour and unemployment in large scale (Ladejinsky, 1969).

Dhanagare provides a critical assessment of green revolution as it differently affected both growth and social justice in India. He argues that in most parts, the green revolution has failed to raise incomes of the rural poor and contribute substantially to enhance their effective purchasing power in the growing market (Dhanagare, 1987). The levels of economic polarization and social antagonism in the form of class conflicts have emerged very quickly than originally anticipated (Francine, 1972). In similar lines, T. K. Oommen (1975) had analyzed the impact of green revolution on the weaker sections of India. He concluded that small peasants did not benefit as much as the landlords because of their poor resources. He further pointed out that the disparity between the small peasant and the agricultural labour has narrowed down and the former is increasingly getting impoverished and tends to join the ranks of agriculture labour. Thus the green revolution does not lead to the welfare of agrarian poor unless substantial alterations in the prevalent-socioeconomic and political structures are done at the grass root level. Green Revolution not only quickened the process of economic polarization both in rural and urban settings, but it has also contributed its major share to increase social antagonism between landlords and tenants, landlords and laborers. The levels of economic polarization and social antagonism in the form of class/caste conflicts have emerged, as a result of implementing green revolution technology, very quickly than originally anticipated.

The problem of poverty and hunger still exist in those places wherein the green revolution technology was claimed to be successful. Literary percentage of the farmers was very low when this technology introduced in India. Farmers do not know how to use green revolution technology and their economic standard did not allow them to afford for mechanization of agriculture across the states in India. It was like introduction of modern technology into Indian society wherein medieval social relations were prevailing i.e. Jajmani system; land ownership and agriculture were the most important domains in such social relations. Due to the failure of land reforms implementation, these social relations determined by Jajmani system took a different shape with the introduction of modern technology into the Indian agriculture: It is like the old wine in a new bottle. Landlords, who were the newly emerging political class in modern India, were largely successful in retaining their lands and their ownership under modern law. It was used as a political trick to sideline the question of land distribution according to the land reforms act, if implemented which would have brought about drastic changes in the lives of Indian poor. This green revolution technology was useful to the medium and big landlords of rural India. Sad part of this story is that the implementation of advanced technology has been considered to be an issue of pride on part of the Indian state irrespective of the social structure, and without any regard for consequences and its feasibility.

\section{Economic Reforms}

In another historical attempt to address the problem of hunger and poverty in India, the issue of economic reforms came to the forefront of national debate with many promises. It 
was in the 1990s when almost more than $40 \%$ of Indian population was living below poverty line (BPL) and, therefore, the need for national economic growth was felt an urgent goal to tackle poverty related problems that India was confronting then. In the 1990s, economic reforms were implemented with a view to unleash the entrepreneurial forces from the shackles of government control and regulations hoping that some of the promoses of economic growth would trickle down to the clamoring masses in India (Bardhan 2003). For Bardhan, after independence the policymaking-elite in India launched a project of economic development with a heavy involvement of the state and democratic polity. There were many success and at least as many failures of this developmental project since the initial decades of 1950s, 60s and 70s. In terms of economic success, this particular project led to the foundation of a complex industrial economy, some parts of which are highly inefficient and not very cost-effective.

This project also led to a fairly reasonable rate of agricultural growth with subsidized irrigation and chemical fertilizers, sometimes at the cost of a heavy fiscal burden as well as environmental degradation. The political mobilizations gave rise to the aspirations of groups that now came up from below, overcoming a long history of social inequality and oppression, but the economy could not match those aspirations. Due to the slow growth, the elite that controlled the economy did not have adequate state resources to placate those who were knocking at the gates with increasing assertiveness; this obviously led to economic and political frustrations and social fragmentation. This began to be widely felt in the middle of 1970s (Bardhan, 2003). Partly in response to this rising frustration, the elite in India over the past few decades launched a process of economic reform with a view to unleash the entrepreneurial forces from the shackles of state control and regulations.

Delicensing and deregulation of investment and production process in most industries; Discontinuation of exclusive reservation of many key industries for the public sector and of budgetary subsidies to public sector enterprises, with some small steps towards privatization in more recent years; Gradual abolition of quantitative restrictions on imports (except for some consumer goods); Movement towards a market-determined exchange rate (within limits); Reduction of average levels of direct and indirect taxes and some streamlining and rationalization of the tax structure (Bardhan, 2003). High levels of poverty in late 1980s have enhanced the importance of orientation towards hunger-free India. The most sort out results from the implementation of economic reforms were: a higher rate of growth, an enlargement of employment potential, reduction of population below poverty line (BPL), promotion of equity and reduction of regional disparities. The impact of economic reforms is, in one sense seen as vital achievement of economic reforms in Indian society, that it managed to create winners and losers as an extension of Indian social system that

\footnotetext{
${ }^{5}$ Populist schemes apparently look attractive at the outset, but in terms of concrete output they absolutely produce zero results. Interestingly they bring about enough popularity to the political party who initiates as well its leaders.

${ }^{6}$ In Indian context, caste-poverty means being in close relationship with poverty by the virtue of born in a certain community/caste group. Some caste groups have very little chances of aspiring for better life since they live in utter poverty in terms of economic as well as socio-political resources. In case of caste-developed, things are completely opposite as the resources of few caste groups effectively work in their favour and increases their chances of improving financial status along with social status.
}

works in favor of a few and against the majority (Tandon, 2003). The contribution of economic reforms towards creating a gulf between the rich and poor would cost India a lot as to bridge that gap is not likely anywhere in the near future.

\section{Conclusion}

Bardhan (2003) seems to provide an interesting dimension to understand the problem of hunger, which has its own set of unique complexities in India. The rise of regional political parties as power centers has become a dominant factor in determining Central government programs or schemes aiming to mitigate hunger. It is apparently clear that Indian nation state failed to provide an effective pan Indian poverty elimination scheme that can effectively be implemented in all the states. Many government programs that are meant to abolish poverty levels, in fact, were largely misused gain some form or the other the political mileage rather than poverty removal, and it holds true at the level of central government and state governments. Even the selection of each region to be benefited under any welfare scheme does certainly involve politics with a sole target of having bright political future for the years to come beginning with the next elections. One among the most significant outputs of such equation resulted in having more and more number of populist ${ }^{5}$ schemes to keep their political parties in the limelight. Such developmental schemes are meant to bring about popularity to political parties, increase prospects to win the next elections, and also make the poor people forever dependents on the development schemes launched by the state.

G. Aloysius (2004) puts forth his argument with much more sociological insights. His point of entry into the political economy of hunger in India is perhaps with a basic question, i.e. who are the poor in India and not so poor? And also, in fact, it tries to address issues centered on a vital and crucial aspect i.e. social face of poverty in India, which had close correspondence with the Indian social structure. Form him, mere economic identification for poor may miss out the very essential social dimensions of poverty and hunger. For the totality of comprehensive identification of poverty in India, no doubt, mere economic identity gives a sense of incompleteness. The hallmark of his argument is to highlight the social face of hunger. His argument classifies the Indian society historically into two major groups, i.e. caste-poverty and caste-developed ${ }^{6}$. From this idea it is apparent to know that, Indian discourse of hunger has been framed by the scholarship with abstract targets. For him, using or writing about poor and poverty without naming who they are and what caste they belong to is a kind of abstract interpretation and such attempts are intended to sideline the question of caste in the whole discourse of poverty and hunger in Indian society.

The shift from the old jajmani social relations to that of modern social relations under the republic of India, especially in the rural India with respect to agriculture and land ownership in modern social relations, was not what it was expected. The agricultural land and land ownership was strongly protected by the landlord class who emerged as a political class right after the independence to protect their vested interests. Both the promises and the failures of land reforms, green revolution and economic reforms in the India's historical experience of dealing with the question of hunger and poverty mitigation have been making new permutations and combinations, once again, to guard the interests of the landlords, by leaving the depressed 
castes to their fate in miserable conditions. As a result, there were not much changes took place in the social relations of people as they managed to retain the traditional caste relations, modified Jajmani relations, without having any substantial changes in land ownership, with unequal distribution of economic resources continue to haunt Indian system with unique problems, short-comings and other social complications. Even today, Indian society is facing the reality of upper caste groups holding an overwhelming bulk of agricultural land while the Indian masses slog for their daily means as agricultural workers.

Those social problems, which were supposed to be solved in the 1960s and 1970s, still exist in the contemporary India. This is what makes the hunger problem more critical and complex due to its inextricable connection with land ownership rights and caste system. But the reasons to start these three major initiatives and questions behind these three important events in the history of Indian development discourse are still relevant and they may continue to be relevant for long. The landlords have reportedly making more money in this globalized world while leaving the Indian poor to their own fate. Failure of public policy, particularly with reference to hunger and poverty, has been a consistent outcome in India since 1960s. It has been a national sport to liquidate the implementation of public policy in India wherein the political class, bureaucracy and landlords are active players who have been leading the game. It is important here to highlight that the direction and methods of poverty alleviation and development discourse are not focused to address the question of power relations and land ownership rights which play a crucial role to determine an individual's capacity to rise out of poverty in a highly hierarchal society like India.

There has been much to say about strong political involvement for development propaganda, just to use "hunger" as an instrument in electoral politics without having any intentions to eradicate of remove it. The development discourse in India is totally delinked from power relations and only trying to address the symptoms of a larger social problem called chronic hunger. The current state of affairs with respect to poverty and hunger in India represents the cumulative effect of the historic blunders, lack of political will, consistency in failure of public policy and the attitude with which the Indian leadership has been approaching the problem of hunger. Even though India is one among the fastest growing economies in the world but the other side of the Indian society seems to be at great risk and it calls for immediate attention before we run out of time.

\section{Acknowledgements}

I sincerely thank Dr. Purendra Prasad, Associate Professor of Sociology at the University of Hyderabad for his guidance and valuable comments on the initial draft of this paper.

\section{REFERENCES}

Aloysius, G. (2004). Poverty and development in India: A sociological consideration. Unpublished Paper.

Arya, P. P., \& Tandon, B. B. (2003). Economic reforms in India: From first to second generation and beyond. Delhi: Deep \& Deep Publications.

Bardhan, P. (2003). Poverty, agrarian structure and political economy in India: Selected essays. New Delhi: Oxford University Press.

Dhanagare, D. N. (1987). Green revolution and social inequalities in rural India. Economic and Political Weekly, 22.

Dreze, J., \& Amartya, S. (1991). The political economy of hunger: Entitlement and well being (Vol. I). Oxford: Oxford University Press. doi:10.1093/acprof:oso/9780198286356.001.0001

Dreze, J., \& Goyal, A. (2003). Future of mid-day meals. Economic and Political Weekly, 38, 4673-4683.

Dreze, J. (2004). Democracy and right to food. Economic and Political Weekly, 39, 723-731.

Frankel, F. (1972). India's green revolution: Economic gains and political cost. Princeton: Princeton University Press.

Joshi, P. C. (1996). Land reforms in India. New Delhi: Sage Publications.

Ladejinsky, W. (1969). Ironies of India's green revolution. New York: Pantheon Books.

Lal, S. K. (1982). Sociological perspectives of land reforms. New Delhi: Agricole Publishing Academy.

Mukherjee, A. (2002). Hunger: Theory, perspectives and realityAnalysis through participatory methods. New Delhi: Concept Publishing Company.

Oommen, T. K. (1975). Impact of green revolution on the weaker sections' in changing agrarian relations in India. National Conference Organized at National Institute of Community Development, Hyderabad, 151-67.

Sharma, M. L. (1989). Land reforms in India: Achievements, problems and prospects. Delhi: Ajanta Publications.

Srivastava, S. P. (1998). The development debate: Critical perspectives. Jaipur: Rawat Publication. 